\title{
KÜLÖNBÖZŐ TÜZOLTÓ SUGARAK ÖSSZEHASONLÍTÓ VIZSGÁLATÁNAK EREDMÉNYEI
}

\author{
COMPARING RESULTS OF DIFFERENT FIRE HOSES ANALYZES
}

\author{
HIMMER Krisztián; PÁNTYA Péter \\ (ORCID: 0000-0001-6817-6457); (ORCID: 0000-0003-2732-2766) \\ himmer@gmail.hu; pantya.peter@uni-nke.hu
}

\begin{abstract}
Absztrakt
A tüzoltási beavatkozások legnagyobb arányban oltóvíz használatával történnek. A különböző oltósugarak hatékonyságát vizsgálva néhány tipikus és egy esetben a hagyományostól eltérő oltási megoldásra kísérletek kerültek lefolytatásra a szerzők által, részvételével. $A$ kérdéskör feltárt elemei és a tüzoltási kísérletek által elérhető oltási hatékonyságok, az elért eredmények - melyek elöadásra kerültek a Nemzeti Közszolgálati Egyetemen is - jelen cikkben széleskörü publikálásra kerülnek.
\end{abstract}

Kulcsszavak: tủzoltás, szivattyú, tüzoltósugár, hatékonyság, sugárcső

\begin{abstract}
During the most of the fire interventions water is used as an extinguishing material. Examining the efficiency of the different jets of water some typical and in one case a new altered way were measured by the authors. The elements of the issue and the measured results - what already demonstrated at the National University of Public Service in Hungary - are widely publishing in this paper.
\end{abstract}

Keywords: firefighting, pump, fire water spray, efficiency, fire nozzle 


\section{ALKALMAZOTT MÓDSZEREK, A VIZSGÁLATOK ALAPVETŐ KÖRÜLMÉNYEI}

A katasztrófavédelmi, tűzoltósági beavatkozások jellemző esetszámban tüzoltási célra irányulnak az alkalmazható különbözö kialakítású tüzoltó sugarak bevetésével. A különbözö tüzoltó sugarak különböző taktikai elvek szerint alkalmazhatóak, azonban vannak átfedések a különböző tűzesetek és így a különböző tűzoltó sugarak alkalmazhatósága, azok teljesítménye és hatékonysága között.

A későbbiekben is felhasználható konkrét mérési eredmények elérése érdekében egységtüz került kialakításra három alkalommal, amikor is három különböző oltósugár hatékonysága külön - külön mérhető volt. Ezen eredmények összehasonlításra kerülnek az azonos és valós tűz oltásának keretében. Ebből megállapíthatóak a különböző sugarak oltási hatékonyságainak konkrét mérési adatai valamint azok egymáshoz viszonyított előnyei és hátrányai.

A hazai katasztrófavédelem, a tüzoltóságok szakfelszereléseinek valóságos körülmények közötti, tudományos alapokon nyugvó méréseinek nincs széles körü hazai és nemzetközi irodalma. A jelen cikkben érintett egyes területeknél publikáló szerzők megtalálhatóak a felhasznált irodalomban úgy mint, Pimper László, Kuti Rajmund és Kanyó Ferenc és Sváb Attila, akik jellemzően a vízzel, egyes esetekben a vízköddel oltás egyes kérdéseiröl, azt ezt működtető tüzoltójármüvekről értekeztek. Külföldön az Egyesült Állomokban több gondolkodás is folyik a tömlők méreteiröl, de a magyar szakfelszereléseknél ezek közvetlenül nem használhatóak fel. A cikk célja érdekében a hazai viszonyok közötti, a rendelkezésre álló szakfelszerelések mérése elsődleges.

A jelen publikáció során is cél a minél szélesebb szakmai és tudományos közönség elérése, a megállapított mérési eredmények megismertetése a Nemzeti Közszolgálati Egyetemen elért sikeres Tudományos Diákköri Konferenciákat ${ }^{1}$ követően. [1] [2]

A minden magyar tüzoltóság szertárában, tüzoltó gépjármüvön megtalálható sugarakat, gépészeti háttért vizsgáltuk meg. A sugarak terén egy hagyományos „C” sugár, egy szintén hagyományosnak mondható „D” sugár (gyorsbeavatkozó) és egy rendelkezésre álló eszközökből összerakott „E” sugár került összehasonlításra a lehető legtöbb szempont alapján ${ }^{2}$.

A főbb vizsgálati célkitüzések:

1. A beavatkozás ideje, gyorsasága

2. Az optimális vízfelhasználás megtalálása (így a vízkárok csökkentése is)

3. A tüzoltók terhelésének csökkentése

4. A vonatkozó szakfelszerelések megfelelöségének vizsgálata [3]

Az egyes vizsgálatok személyi felételei a jelenlegi szakmai szabályozókon alapultak. A tüzoltás alapvető szervezési egysége a raj, mely $1 \mathrm{db}$ gépjármüfecskendőből és 6 fő a szerre beosztott tüzoltóból áll ${ }^{3}$. A tüzoltási végrehajtása során megoldott szerelési feladatokat a 3/2015. BM OKF Főigazgatói Utasítás szabályozza.

\section{AZ EGYES VIZSGÁLATOK LEFOLYTATÁSA}

A vizsgálatok során az MSZ EN 3-7: 2004+A1:2008 szabvány szerinti 13A egységtüz oltására került sor kisebb eltérésekkel. Az „A” tűzosztályú vizsgálati egységtűz a szabvány

\footnotetext{
${ }^{1}$ és az összefoglaló rész szakdolgozati megjelenésében

${ }^{2}$ A sugarak lényegében a sugárcsőből és az oltóvizet biztosító tömlőkből állnak, ahol a „C” sugár esetében „,C” típusú, 52 mm-es átmérőjü tömlővel való megtáplálást jelöl. A „D” sugár jellemzően a tűzoltójárműre előre szerelt és sugárcsővel ellátott, gyorsbeavatkozónak nevezett, $38 \mathrm{~mm}$ átmérőjű merevebb gumitömlő, míg az „E” sugár egy kombinált és módosított összetételü kivitel a „C” sugárhoz hasonló szakfelszerelésekből.

3 A 6 főből 1 fő szerparancsnok, 1 fő gépjármüvezető/szivattyúkezelő és 4 fő beosztott tűzoltó. A végrehajtói állomány 1 rajból 5 fő (gépjárművezető, beosztott tüzoltó).
} 
alapján egy falécekből felépített máglya, melyet fémállványon helyeznek el. A fémállvány magassága $250 \mathrm{~mm}$, szélessége $900 \mathrm{~mm}$, a hossza pedig a vizsgálati egységtüz hosszától függ. A fémállvány $50 \times 50 \mathrm{~mm}$-es szögacélból készül. A $39 \pm 2 \mathrm{~mm}$ méretű, fürészelt falécek anyaga erdei fenyő, melynek nedvességtartalma 10-15 \% között lehet. A faléceket a fémállványon 14 rétegben kell egymásra rakni. Az azonos rétegben lévő falécek között a távolság $6 \mathrm{~cm}$. A vizsgálati egységtüzek szélességét alkotó lécek $50 \pm 1 \mathrm{~cm}$. A hosszanti lécek mérete a meghatározott $13 \mathrm{~A}$ szerint: $130 \mathrm{~cm}, 13 \mathrm{db}$ soronként. A vizsgálati egységtüz hossza (mélysége) a lécek számából, a lécek szélességéből $(4 \mathrm{~cm})$ és a lécek közötti távolságból $(6 \mathrm{~cm})$ számítható.

Az egység tüz mérete 50x130x49 cm-es és a szabványtól eltérően 35x50 mm-es lucfenyő tetőlécből rakott máglya. A szabvány szerint erdei fenyő anyagú 39x39 mm-es léceket szükséges használni. A faanyag keresztmetszetének $15,21 \mathrm{~cm}^{2}$-nek kellene lennie, ezzel szemben a helyettesítő faanyag keresztmetszete $17,5 \mathrm{~cm}^{2}$. A beszerzett faanyag víztartalmát mérésekkel állapítottuk meg, ami 31,3\%-os volt átlagban (mérőeszköz: HOLDPEAK MD2GA fa nedvességtartalom mérö). Az eltérés oka, hogy nem állt rendelkezésre a szabvány szerinti minőségü faanyag.

Az egységtüz oltása 3 alkalommal lett elvégezve:

- „C” sugár, 8 bar, rövid szórt sugárkép

- „E” sugár, 8 bar, rövid szórt sugárkép

- „D” magasnyomású sugár, 20 bar, rövid szórt sugárkép

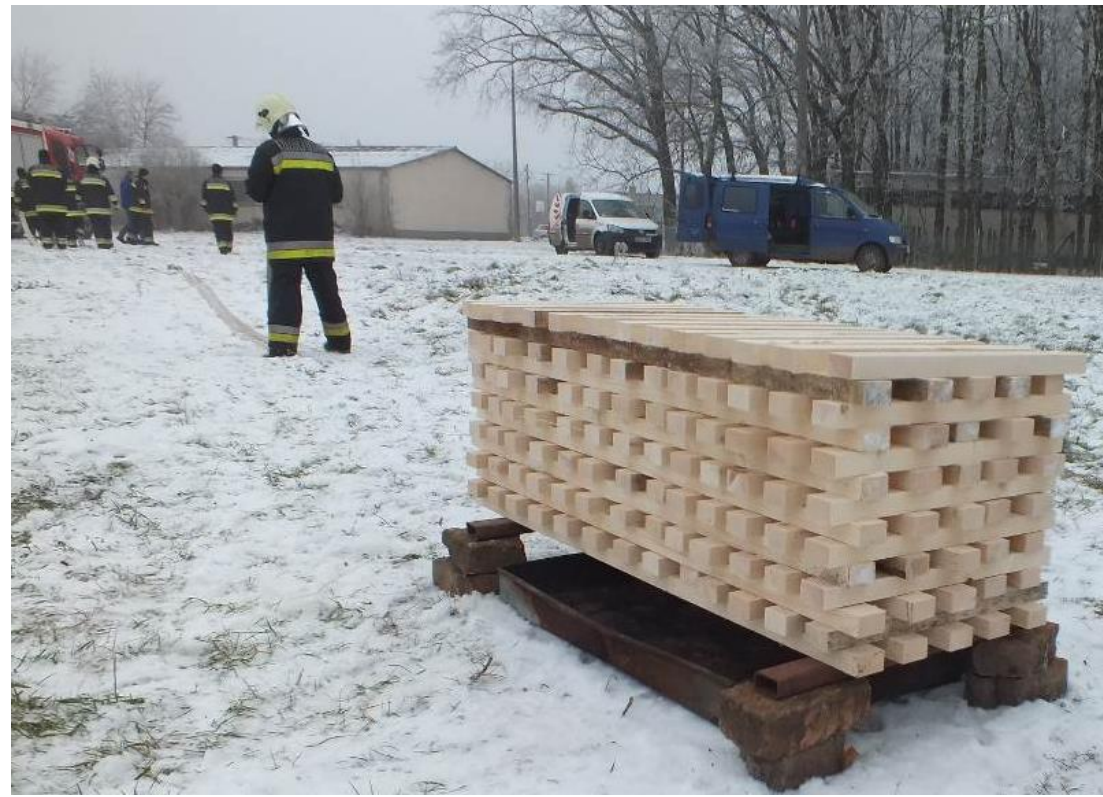

1. kép A közel szabványos 13 A vizsgálati egységtüz máglyája (Himmer Krisztián, 2016)

Az egységtüzek gyújtása az máglyák alá helyezett edényben elhelyezett éghető folyadékkal történt. A begyújtó tálcában $(60 \times 80 \mathrm{~cm}) 3 \mathrm{~cm}(1,44$ l) vízrétegre rátöltött $0,5 \mathrm{~cm}(0,251)$ benzinréteg került elhelyezésre. A begyújtás ideje 2 perc, az előégetés 6 percig tartott, majd ez után kezdődött meg a tüz oltása. A szabvány szerint a tüz oltása akkor sikeres, ha a tűz 3 perc időtartamig nem gyullad vissza. Mind a három oltási kísérlet a fecskendő visszaszerelt állapotából indult, a sugarak nincsenek előkészítve.

A gyakorlat során gyüjtött adatok:

- tüzoltás előkészítésének (a sugár szerelésének, a víz megjelenésének) időtartama (másodperc)

- oltás időtartama (másodperc)

- oltáshoz felhasznált oltóanyag szállítási mennyisége (liter/perc) 
- időjárási körülmények, levegő hőmérséklete (Celsius fok)

- oltóanyag hőmérséklete (Celsius fok)

A gyüjtött adatok jegyzőkönyvben kerültek rögzítésre.

A gyakorlat anyagigénye:

- 1 db gépjármüfecskendő, Renault Aquadux 2000

- átfolyás mérő, Flowmeter EMF - 300 E hitelesített vizsgálómüszer4

- begyújtó tálca, kb. 5 liter víz, kb. 0,75 liter benzin

- tetőléc 3,5x5 cm, lucfenyő, kb. $300 \mathrm{~m}$

- időmérő eszközök

- hőmérő eszköz

- oltóvíz a gépjármüfecskendő tartályában

- optikai eszközök: fényképezőgép, kamera

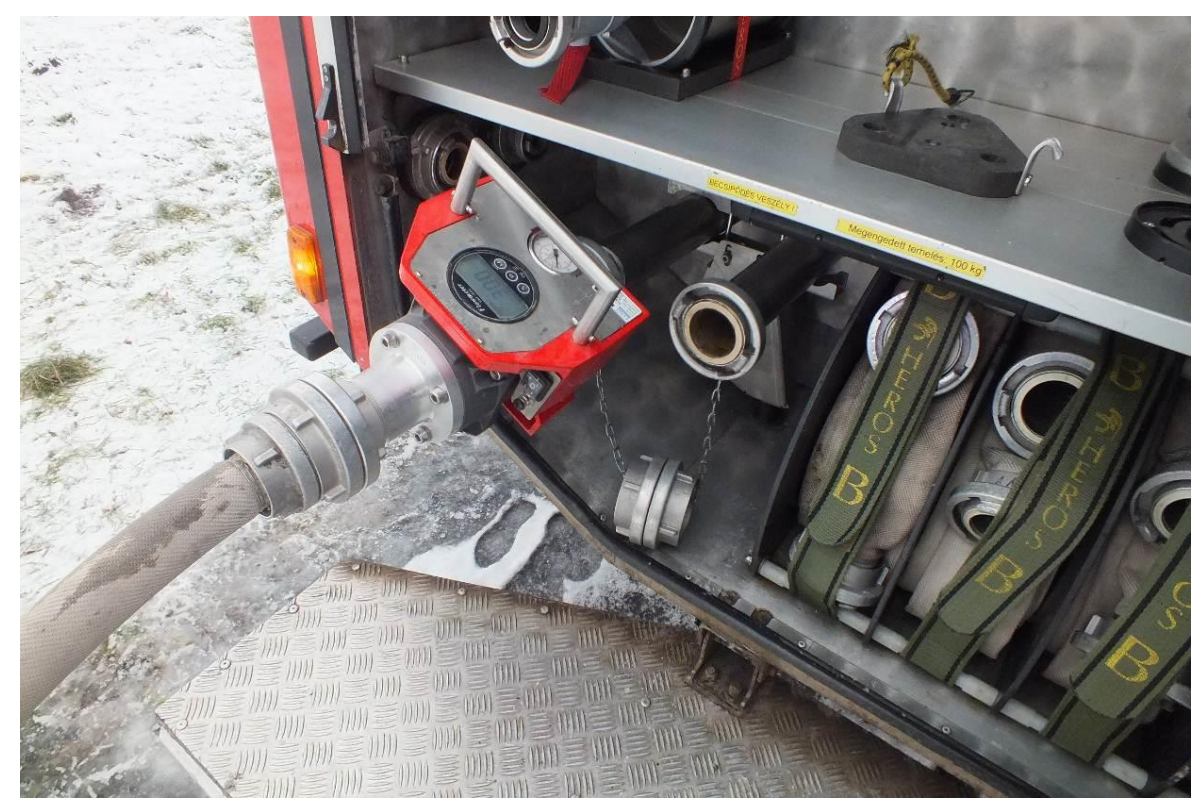

2. kép Az átfolyás mérő müszer az alapvezetékbe került beiktatásra (Himmer Krisztián, 2016)

\section{A sugarak szereléséhez szükséges eszközök, a felhasználási módok összehasonlítása}

A jelölések értelmezésének érdekében először érdemes ismertetni azokat a szabvány szerinti tüzoltótömlő osztályokat, melyek a vizsgálatban szerepelnek.

${ }^{4}$ A HESZTIA Kft. bocsájtotta rendelkezésre, Hesztia Debrecen Tűzvédelmi és Biztonságtechnikai Kft. 


\begin{tabular}{|c|c|}
\hline Jelölés & Átmérö $(\mathrm{mm})$ \\
\hline $\mathrm{B}$ & 75 \\
\hline $\mathrm{C}$ & 52 \\
\hline $\mathrm{D}$ & 25 \\
\hline $\mathrm{E}$ & 38 \\
\hline $\mathrm{H}^{*}$ & 38 \\
\hline
\end{tabular}

1. táblázat, A vizsgálatban érintett tűzoltó tömlők méretei (*: magasnyomású tömlö, forrás: MSZ 1185:2016)

\section{A három vizsgált sugártípus a következő:}

Az első sugár összeállítása: a tüzoltógépjármű „B” $(75 \mathrm{~mm})$ nyomócsonkjára $1 \mathrm{db}$ „B” tömlő kerül, ennek a végére egy osztót helyezünk, majd egy „C” $(52 \mathrm{~mm})$ tömlővel folytatódik a vezeték, melyre egy „C” „Fogfighter” sugárcsövet kapcsolunk. Ez a klasszikus alkalmazási mód.

A második egy szintén hagyományosnak mondható „D” $(25 \mathrm{~mm})$ gyorsbeavatkozó sugár, mely egy dobra felcsévélt 60 m-es gumitömlőből, és egy hozzá kapcsolt magasnyomású „D” sugárcsőből áll.

A harmadik esetben ötvözzük a két előző felszerelést. A nyomócsonkra egy „C” alapvezeték kerül, majd az osztó után egy 38, „H” tömlőt illetve a hozzá való sugárcsövet csatlakoztatjuk. Az átmérő különbségek kiküszöbölésére a gépjármüre málházott áttéteket használjuk.

A fenti összeállítások vizsgálata során két esetben 8 bar, a gyorsbeavatkozó sugár esetében 20 bar az alkalmazott nyomás.

\section{A felszerelések tömege}

A felszerelés súlya nem elhanyagolható a beavatkozó állomány tekintetében. A nagy igénybevételnek kitett tüzoltók munkavégzése során minden kilogramm számít. A védőruha, és más védőfelszerelések eleve korlátozzák a mozgást, és az érzékszerveket, ezért minden megspórolt energia a beavatkozás hatékonyságát növeli.

Az általános tüzoltás során „C” sugár szereléséhez a beavatkozó állomány magával visz 2 $\mathrm{db}$ „C" tömlöt, egy sugárcsövet, egy osztót, valamint egy sugárcsőkötelet amennyiben a sugarat magasba szerelik. A gyorsbeavatkozó estében ezekre nincs szükség, csak a sugárcsőkötél használata indokolt magasba szerelés esetén. ${ }^{5}$

Az MSZ 1185:2016, és az MSZ EN 1947:2014 szabványok szerint a száraz vízzáró lapostömlök és kapcsok megengedett súlya az alábbi táblázat szerint alakul (a tömlök betűjelzését a cikk további részében nem emeljük ki idézőjellel):

\begin{tabular}{|c|c|c|c|}
\hline Jelölés & $\begin{array}{l}\text { tömeg } \\
(\mathrm{g} / \mathrm{m})\end{array}$ & $\begin{array}{l}\text { kapocs tömege } \\
(\mathrm{kg})\end{array}$ & $\begin{array}{l}\text { 20m-es tömlö } \\
\text { tömege }(\mathrm{kg})\end{array}$ \\
\hline $\mathrm{B}$ & 550 & 1,1 & 13,2 \\
\hline $\mathrm{C}$ & 350 & 1,5 & 10 \\
\hline $\mathrm{D}$ & 180 & 0,7 & 5 \\
\hline $\mathrm{E}$ & 240 & 0,85 & 6,5 \\
\hline $\mathrm{H}$ & 240 & 1,5 & 7,8 \\
\hline
\end{tabular}

2. táblázat, Száraz tüzoltó tömlők súlya (forrás: MSZ 1185:2016)

\footnotetext{
${ }^{5}$ A kiépített oltósugarakat, az azokat ellátó vezetékrendszert, és más tűzoltó eszközöket a BM OKF 3/2015. számú főigazgatói utasítása, vagyis a szerelési szabályzat alapján szerelik meg, illetve használják a tűzoltók.
} 
Az osztó és a sugárcsőkötél tömege nincs elöírva, a sugárcsövek közül a „Fogfighter”-röl nincs gyári adat, ezért az értékek konyhai mérleg segítségével történő méréssel kerültek megállapításra.

- osztó (B-CBC): 4,5 kg

- sugárcsőkötél (fém orsó, $30 \mathrm{~m}$ ): $2 \mathrm{~kg}$

- Fogfighter 175/450 sugárcső: $2,5 \mathrm{~kg}$

Az alábbi felszerelések tömegének gyári adatai:

- Protek Style 361 sugárcső: 1,1 kg.

- Magasnyomású gumitömlő (40-60-90Bar): 0,88 kg/m.

\section{Az elsö összeállítás adatai}

Súlyadatok az első sugár esetén:

- $1 \mathrm{db}$ B tömlö: $13,2 \mathrm{~kg}$

- $1 \mathrm{db}$ osztó: $4,5 \mathrm{~kg}$

- $1 \mathrm{db}$ C tömlö: $10 \mathrm{~kg}$

- $1 \mathrm{db}$ Fogfighter sugárcső: $2,5 \mathrm{~kg}$.

Összesen: 30,2 kg

A B alapvezetékben lévő víz súlya méterenként $4,41 \mathrm{~kg}$, a $\mathrm{C}$ tömlővezetékben lévő víz súlya méterenként $2,12 \mathrm{~kg}$.

\section{A második összeállítás adatai}

Súlyadatok második sugár esetén:

- 40 m gumitömlö: $35,2 \mathrm{~kg}$

- Protek Style 361 sugárcső: $1,1 \mathrm{~kg}$

Összesen: 36,3 kg

Magasba szerelés esetén - jelen esetben nem releváns - csak egy sugárcsőkötelet kell vinni, amely 2 kg. ${ }^{6}$

\section{A harmadik összeállítás adatai}

Súlyadatok második sugár esetén:

- $\quad 1 \mathrm{db}$ C tömlö: $10 \mathrm{~kg}$

- 1 db osztó: $4,5 \mathrm{~kg}$

- $\quad 1 \mathrm{db} H$ tömlö: $7,8 \mathrm{~kg}$

- 1 db Protek Style 361 sugárcső: 1,1 kg.

Összesen: $\mathbf{2 3 , 4} \mathbf{~ k g}^{7}$

\section{A sugárnemek ismertetése, a taktikai, alkalmazási lehetőségek}

A hagyományos $\mathbf{C}$ sugár a klasszikus oltósugár forma. B alapvezetékből, osztóból valamint 1-2 db C sugárból áll. A tömlők $20 \mathrm{~m}(+/-10 \%)$ hosszúságúak, nagy oltásteljesítmény jellemzi.

Elönye, hogy a tömlőkből és szerelvényekből álló alapvezeték és sugár bármilyen kombinációban, hosszban, magasságban összeállítható. Az oltási viszonyok beavatkozás közbeni megváltozására hatékonyan reagálhat az állomány. A felállítási, müködési hely megváltoztatása, további sugarak megszerelése, a sugarak hosszabbítása, visszavonása egyszerüen megvalósítható. Ezek mind a szerelési szabályzatban is rögzített folyamatok.

\footnotetext{
${ }^{6}$ Felhúzáskor figyelemmel kell lenni arra, hogy a tömlő vízmentes legyen, mert különben ez méterenként 1,13 $\mathrm{kg}$ többlet-terhet jelent.

${ }^{7}$ Magasba szerelés esetén a felszerelés: 2 db H tömlö, 1 db osztó, $1 \mathrm{db}$ sugárcső, $1 \mathrm{db}$ sugárcsőkötél: 23,2kg. A

C alapvezetékben lévő víz súlya méterenként $2,12 \mathrm{~kg}$.
} 
Hátránya, hogy a fix hosszúságú tömlők nem minden esetben egyeznek meg a kívánt mérettel. Ekkor akár több kunkorodás képződhet, melyeket nehéz eligazgatni, és a biztonságos mozgást is veszélyeztetik. Továbbá a sugárvezetőkre is nagy megterhelést jelent a nyomás alatti, vízzel teli tömlőkkel történő mozgás, és a sugár irányítása. A sugárcső zárása, nyitása miatti impulzusok szintén veszélyeztetik a beavatkozó állományt, a rendszer kiépítése időt vesz igénybe az adott terep-, valamint épületviszonyok függvényében.

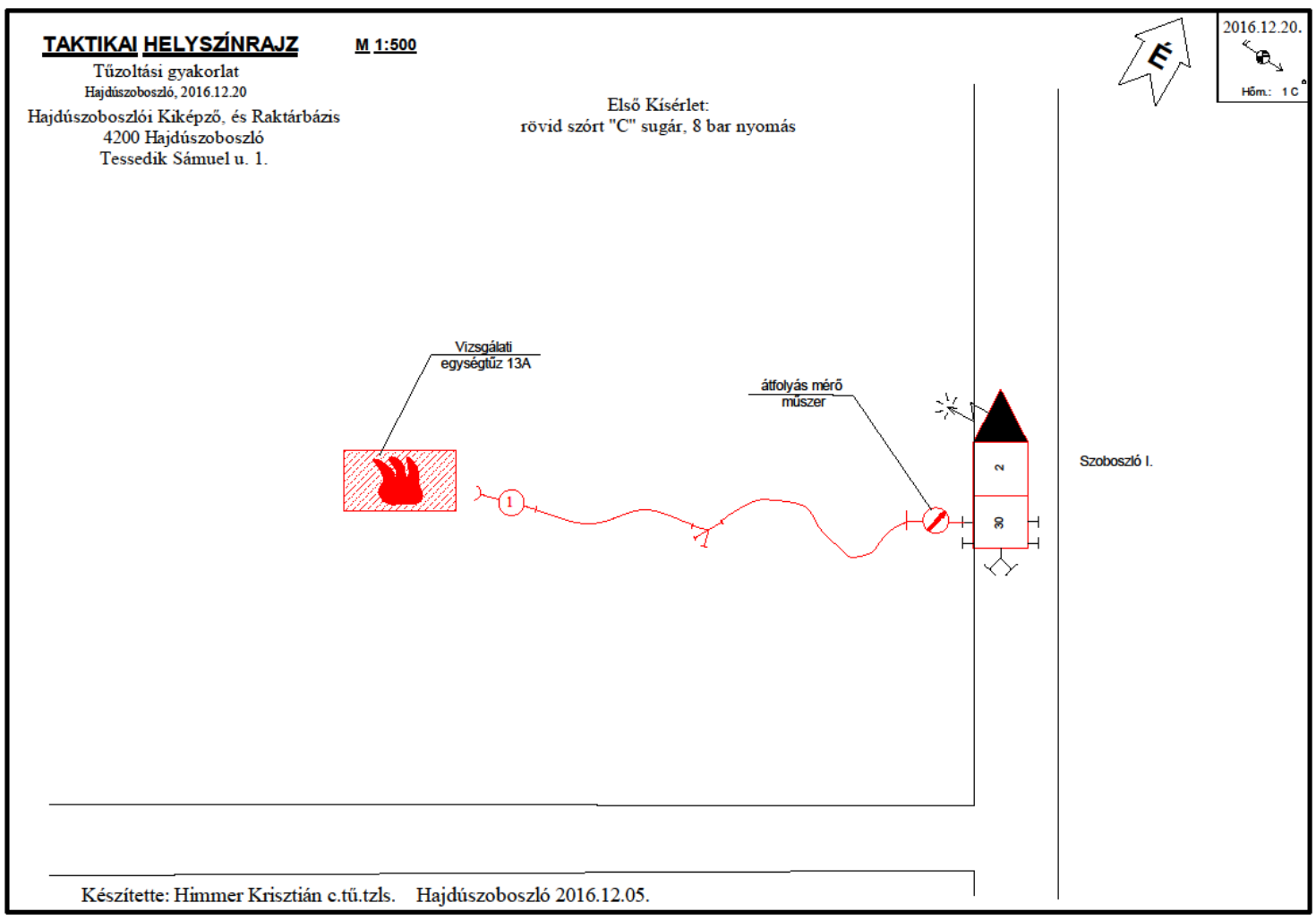

1. ábra A vizsgálati gyakorlat terve $C$ sugár esetén (Himmer Krisztián szerkesztése, 2016)

A magasnyomású gyorsbeavatkozó (D) általában $60 \mathrm{~m}$ hosszú gumitömlőből és a hozzá csatlakoztatott magasnyomású sugárcsőből áll.

Előnye, hogy nagyon gyorsan bevethető. A tömlődobról lehúzva hamar a beavatkozás helyszínére telepíthető és alkalmazható, könnyen mozgatható, irányítható. A magasnyomásnak (20-40 bar) köszönhetően fokozott mechanikai oltóhatás valamint nagyon jó vízporlasztási képesség jellemzi.

Hátránya a korlátozott hosszúság. Lehet hosszabbítani lapostömlővel, de ennek is van hátránya, további sugarak megszerelése nem lehetséges. Bonyolultabb épület esetén fennáll az elakadás veszélye, a sarkoknál külön tüzoltó lehet szükséges a tömlő behúzásának segítéséhez. A hosszan lehúzott tömlő mozgatása a teljes raj állományát igénybe veheti. Magasba szerelés esetén szintén korlátozott a felszerelés hossza, melyből a behúzás magassága is elvesz, valamint nehezen rögzíthető. Visszaszereléskor a tömlődobról lehúzott hossz vízzel van tele, ennek a leeresztése nem, vagy csak nehezen megoldható.

A kísérleti jellegü $\mathbf{E}$ sugár $C$ alapvezetékből, C-ECE osztóból (melyet az MSZ EN 1947:2014 szabvány és a gyártók is ismernek), E - jelen esetben $\mathrm{H}$ - lapostömlöből és D sugárcsőből áll. További tulajdonságai, megszerelésének módjai megegyeznek a $\mathrm{C}$ sugárral. Ez a megoldást azért van kísérletinek nevezve, mert jelenleg ilyen, vagy hasonló összeállítást jellemzően nem használ a magyarországi tüzoltó és a konkrét hatékonysága jelen vizsgálat szerint kerül mérésre. 
Ha a rendelkezésre álló $H$ tömlö helyett az E tömlőt használjuk, akkor a sugár felszerelés tömege akár 9,6 kg-mal csökkenthetö. Az E és a $\mathrm{H}$ tömlö átméröje azonos. A különbség közöttük az, hogy a H tömlö nehezebb kapcsokkal, illetve erősített vászonburkolattal rendelkezik, mivel a $\mathrm{H}$ tömlő magasnyomású sugár szerelésére is alkalmas. A sugarak mozgatása, irányítása a kisebb tömlő átmérő és súly miatt sokkal könnyebb, mint a vastagabb, nehezebb C sugár esetében.

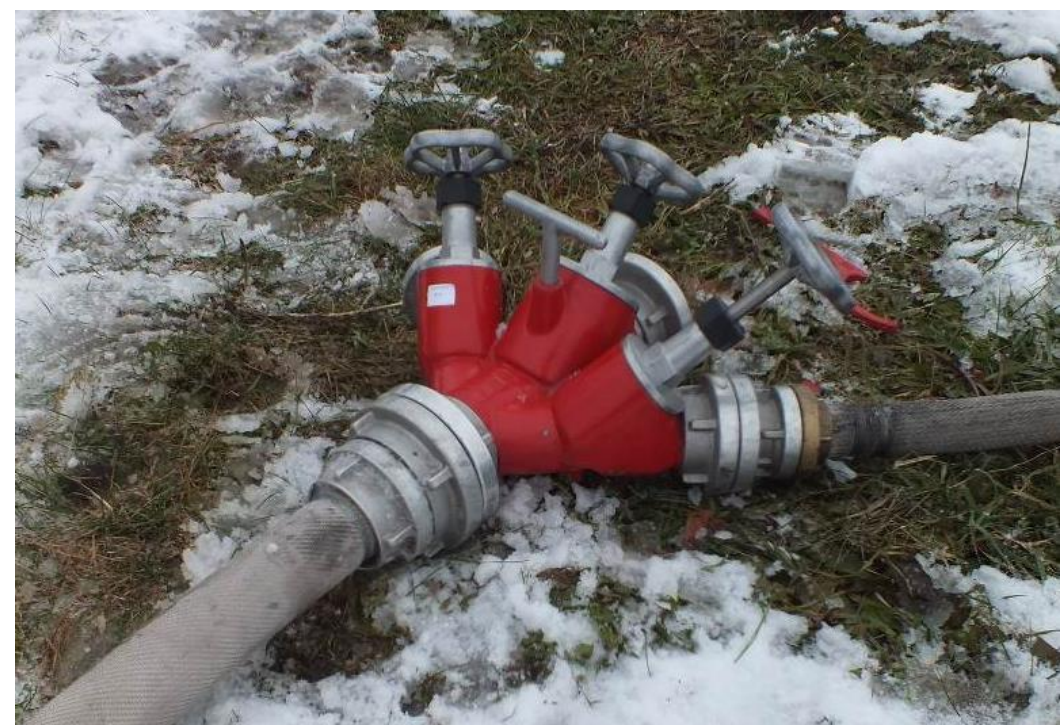

3. kép A csökkentett átmérőjű kísérleti alapvezeték és sugár összeállítása (Himmer Krisztián, 2016)

A gyakorlat végrehajtása 2016 december 20.-án történt, az időjárás borult, párás volt, néha enyhe légmozgás volt tapasztalható, a hömérséklet $-4,5$ Celsius fok volt. A kísérletek végrehajtásának ideje alatt nem változott az időjárás, a gyakorlat mérési eredményeit nem befolyásolta. A gépjármüfecskendő tartályában a víz 16 Celsius fokos volt.

\section{A TÜZOLTÓ ESZKÖZÖK JELLEMZÖ HASZNÁLATA, A VIZSGÁLAT INDOKOLTSÁGA ÉS A MÉRÉSI EREDMÉNYEK}

A tüzoltási beavatkozás hatékonysága lemérhető a tüzoltás előkészítésének, oltásának idejéből, a felhasznált oltóanyag mennyiségéből, az eszközök használati módjától, az erre fordított emberi, és anyagi erőforrás mértékéből valamint a végeredménytől. $\mathrm{Az} \quad$ anyagi erőforrás magában foglalja a tüz oltásához szükséges felszerelés, oltóanyag, emberi erő készletezésének, tárolásának, helyszínre szállításának, energiaellátásának költségét, aminek keretrendszere a tüzoltó gépjármüvek családja, hiszen ezek az eszközök végzik ennek a logisztikai feladatnak az alapját. [4] [5]

A tüzoltás előkészítése és végrehajtása függ a kárhelyszín típusától, építési sajátosságaitól, megközelíthetőségétől, egyéb veszélyforrások jelenlététől, és olyan környezeti körülményektől, mint például a füsttel való telítettség, vagy hő terhelés.

A felhasznált oltóanyag jellemzően víz. Ennek a felhasznált mennyisége nagyban függ az alkalmazott tűzoltó sugár típusától, és az azt üzemeltető tüzoltó rutinjától, felkészültségétől. Az 1980-as, 1990-es években a tüzoltók a kötött „C” sugarat alkalmazták jellemzően, ezzel másodlagos károkat ${ }^{8}$ tudtak, és manapság is tudnak okozni. Az elmúlt tíz évben azonban már eltérés mutatkozik az alkalmazott tüzoltó sugarak, és sugárnemek terén. [6]

\footnotetext{
${ }^{8}$ Másodlagos kár: a tüzoltói beavatkozás során, a beavatkozás következményeképpen létrejövő vízkárok, valamint épületkárok.
} 
Az 1995 év statisztikáiban arról számolnak be, hogy C sugarat 15800 esetben, míg D sugarat 3676 esetben használtak a tüzoltók. Érdekességképpen mutatták be milyen látványos a D sugár térhódítása. [7] Egy rövid írásban, de hosszú időszak elemzésében látható az Egyesült Államokban is többször változott az alkalmazott tömlörendszer, de manapság is vannak e téren további, a méretet érintö gondolatok [8] [9]

Az 1. sz. diagramból látszik, hogy a 90-es évekhez képest megfordult az alkalmazott sugártípusok közötti arány.

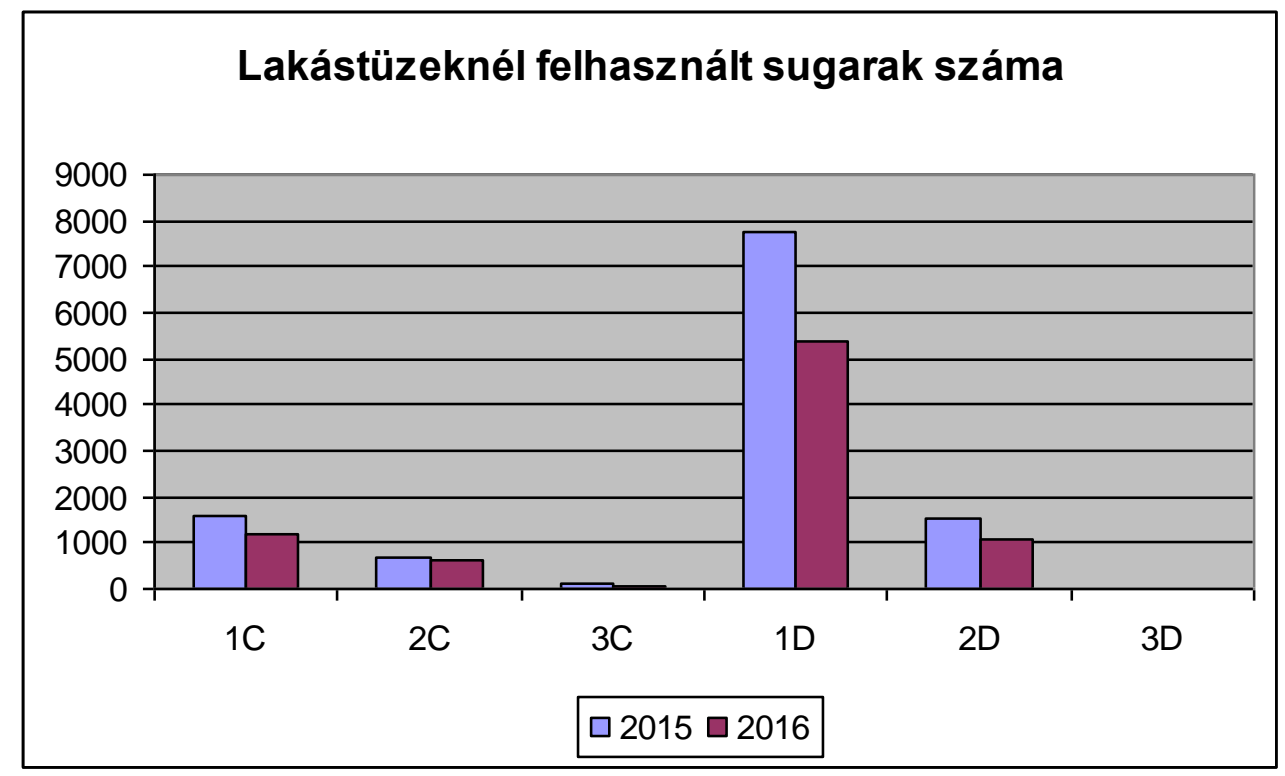

1. diagram Lakástüzeknél bevetett sugarak száma és típusa (A KAP online adatai alapján szerkesztette Himmer Krisztián, 2016)

A diagramon a 2015. és 2016. évek lakástüzeinek során bevetett sugarak adatai látszanak. Látszik, hogy a $\mathrm{C}$ sugarat ritkábban használjuk, míg a $\mathrm{D}$ sugár erőteljesen előtérbe került. Ennek oka lehet teljesen egyszerü. A D sugár használata jóval kevesebb energiát igényel a beavatkozó állománytól is, azonban, ha a $\mathrm{D}$ sugár nem lenne hatékony a tüzoltás során, akkor a bevetési száma sem növekedne.

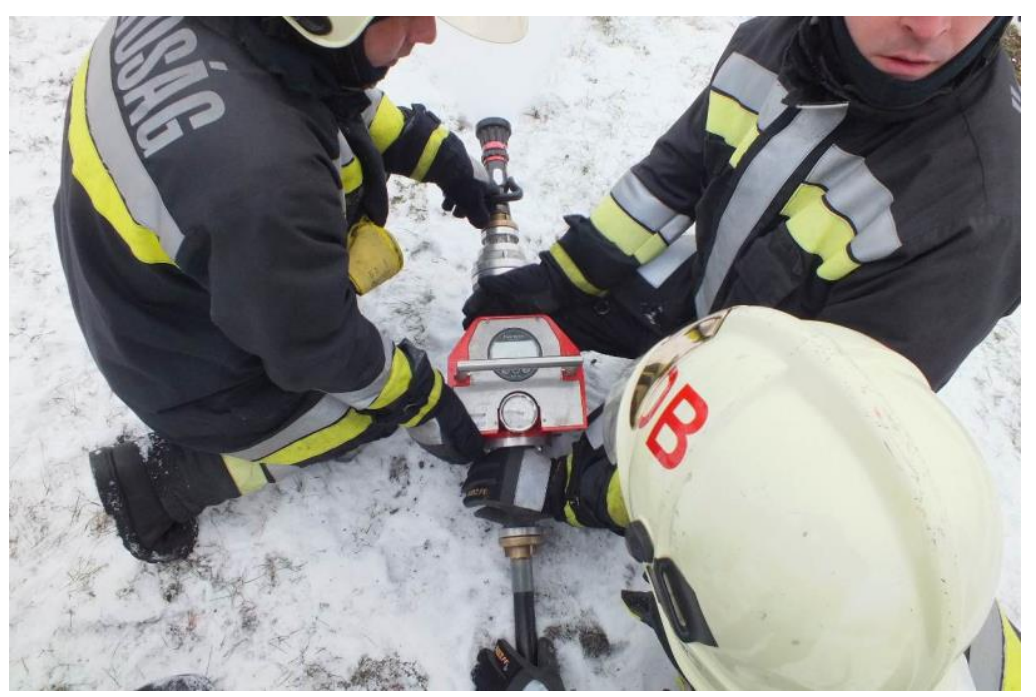

4. kép A magasnyomású gyorsbeavatkozó szállított vízmennyiségének bemérése (Himmer Krisztián, 2016) 
Mik azok a tulajdonságai a kisebb paraméterekkel rendelkező sugártípusnak, melyek ilyen népszerüvé teszik? Ez az a kérdés, melyet érdemes közelebbröl megvizsgálni és tapasztalati adatokkal is alátámasztani. A tüz oltását vezető parancsnok, ha megfelelő ismeretekkel rendelkezik az eszközök valódi képességeiről, tulajdonságairól, szakszerüen dönthet kisebb sugarak alkalmazásáról. Ezek kímélik állományának erőit, kevesebb oltóanyagról kell gondoskodnia, kevesebb másodlagos kárt okoz. Ne felejtsük el, hogy minden felelősség őt terheli.

A rendelkezésre álló tüzoltó eszközök optimális használatához gyakorlatra van szükség, ezen kívül tudományos megközelítés is szükséges, hiszen a kipróbált és kielemzett használati technikák nagyban lerövidítik az amúgy tapasztalaton alapuló - akár több éves - kialakulást. A használat optimalizálása nem jelent feltétlenül új eszköz beszerzést, csak a meglévő eszközeinket használjuk másképp, racionálisabban. Ha ezek az új módú alkalmazások költség és kárenyhítő hatásúak is, akkor szinte ingyen jelentős fejlesztést érhetünk el az oltási hatékonyság terén. [10]

\section{A vizsgálat végrehajtása és a mért eredmények}

Az első oltás során a tüzoltás előkészítésének ideje 45 másodperc, a tüz eloltásának ideje 36 másodperc, a szállított vízmennyiség 410 1/perc volt.

A második oltás során a tüzoltás előkészítésének ideje 40 másodperc, a tüz eloltásának ideje 21 másodperc, a szállított vízmennyiség 300 1/perc volt.

A harmadik oltás során a tüzoltás előkészítésének ideje 24 másodperc, a tüz eloltásának ideje 12 másodperc, a szállított vízmennyiség 250 1/perc volt.

Az eredmények táblázatban összefoglalva, aláhúzva az egyes legjobb értékeket:

\begin{tabular}{|c|c|c|c|c|c|}
\hline $\begin{array}{c}\text { A sugár neme, } \\
\text { nyomása, } \\
\text { sugárképe }\end{array}$ & $\begin{array}{c}\text { A tűzoltás } \\
\text { elökészítésének } \\
\text { időtartama }(\mathrm{mp})\end{array}$ & $\begin{array}{c}\text { A tüzoltás } \\
\text { időtartama (mp) }\end{array}$ & $\begin{array}{c}\text { A szállított } \\
\text { oltóanyag- } \\
\text { mennyiség } \\
(1 / \mathrm{min})\end{array}$ & $\begin{array}{c}\text { Felhasznált } \\
\text { oltóanyag } \\
\text { mennyiség } \\
(\mathrm{l})\end{array}$ & $\begin{array}{c}\text { Tüzoltás } \\
\text { teljes } \\
\text { ideje } \\
(\mathrm{mp})\end{array}$ \\
\hline $\begin{array}{c}\text { „C" sugár, 8 } \\
\text { bar, rövid szórt } \\
\text { sugárkép }\end{array}$ & $\mathbf{4 5}$ & $\mathbf{3 6}$ & $\mathbf{4 1 0}$ & $\mathbf{2 4 6}$ & $\mathbf{1 2 1}$ \\
\hline $\begin{array}{c}\text { „E” sugár, } 8 \\
\text { bar, rövid szórt } \\
\text { sugárkép }\end{array}$ & $\mathbf{4 0}$ & $\mathbf{2 1}$ & $\mathbf{3 0 0}$ & $\mathbf{1 0 5}$ & $\mathbf{1 0 1}$ \\
\hline $\begin{array}{c}\text { „D” } \\
\text { magasnyomású } \\
\text { sugár, 20 bar, } \\
\text { rövid szórt } \\
\text { sugárkép }\end{array}$ & $\underline{\mathbf{2 4}}$ & $\underline{\mathbf{1 2}}$ & $\underline{\mathbf{2 5 0}}$ & $\underline{\mathbf{5 0}}$ & $\underline{\mathbf{3 6}}$ \\
\hline
\end{tabular}

3. táblázat A vizsgálat során mért eredmények (Himmer Krisztián, 2016)

\section{KÖVETKEZTETÉSEK}

A vizsgálatok során mért eredmények alátámasztják az előzetes feltevéseket a taktikai, előkészítési, és alkalmazási szempontoknál. A felvételek elemzése alapján megállapítható, hogy a beavatkozó állomány egyre gyorsabban, hatékonyabban avatkozott be, ennyi idő alatt is jelentkezik a tapasztalat, ami kihathat a mérési eredményekre. Ezek az eltérések minimális különbséget jelentenek azonban, az eredmények elemzése során elhagyhatók.

Az eloltás idejének vizuális meghatározása pontosan nem lehetséges a keletkező gőzfelhő miatt. Ennek a megállapítása hang alapján történt, mivel a faanyag szerencsére hangos 
ropogással égett. A felvételek alapján látszik, hogy a tüz oltását végzők a kisebb átmérőjü és súlyú sugarakat sokkal könnyebben mozgatták és irányították. Ez kimutatható az oltási idők esetében is.

A C sugár bevetése során az előkészítés ideje megfelel az általános szerelési időknek. Ami meglepő eredményt jelentett, az a tüz eloltásának ideje. A három kísérlet közül ez a legnagyobb oltóképességü sugár, mégis ez került a dobogó harmadik fokára. A beavatkozás során megfigyelhető volt, hogy nehézkes a sugár irányítása, a vele való mozgás. A tömlöben lévő víz tömege a többi megoldáshoz képest jobban terheli a beavatkozó állományt.
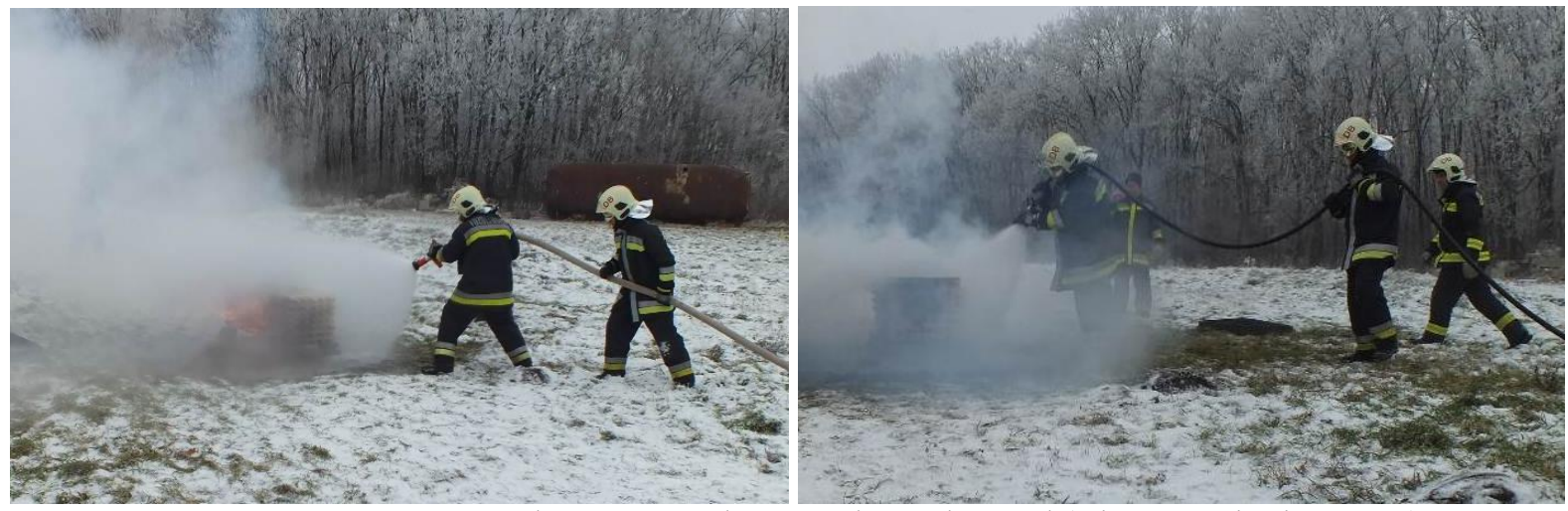

4. és 5. képek Oltás C sugárral és gyorsbeavatkozóval (Himmer Krisztián, 2016)

A második, kísérleti sugár (lapostömlős E) összeállítás, mely ötvözi a klasszikus sugarat a gyorsbeavatkozó sugár jellemzőivel, meglepő eredményt hozott. A várakozás C sugárral megegyező, vagy az alatti jellemzőkre volt, a vizsgálat ettől jobb oltóhatást eredményezett. Megállapítható, hogy a normál nyomású E sugár hatékonyan ötvözi a két eddig alkalmazott sugárfajta elönyeit.

A magasnyomású D (hagyományosnak tekinthető gyorsbeavatkozó, tüzoltó-gépjármüre épített) gyors előkészítési és oltási ideje, valamint a felhasznált oltóanyag mennyisége jóval kevesebb a $\mathrm{C}$ sugárénál. Ez a korábban említett tárolási, készenléti-, előkészítési módból, a magasnyomás adta optimális vízporlasztásból és az alacsony szállított vízmennyiségből adódik. Az alkalmazási hátrányát továbbra is a korlátozott hosszúság, valamint taktikai, alkalmazási képességek jelentik.

A sugarak oltóhatásának részletesebb vizsgálatához a kapott eredmények további feldolgozása szükséges, melyek publikálása a későbbiekben várható.

\section{FELHASZNÁLT IRODALOM}

[1] HIMMER Krisztián: Tüzoltó sugarak tulajdonságainak és oltóhatásainak vizsgálata, fejlesztési lehetőségei, TDK dolgozat, NKE, Budapest, 2016 ősz

[2] BLESZITY János, FÖLDI László, HAIG Zsolt, NEMESLAKI András, RESTÁS Ágoston: Engineering science researches and effective government (Part 1.), American Journal Of Research Education And Development 2017/1 sz.: pp. 17-34. (2017)

[3] NOSKÓ Zsolt: Tüz és víz: avagy vízpazarlás a tüzoltások során pp. 18-19. , 2 p., In: Egyed, Adrienn Beatrix; Kúti, Zsuzsanna (szerk.) Meddig lesz még Föld Napja? Doktoranduszok I. Környezettudományi konferenciája, Budapest: Doktoranduszok Országos Szövetsége, (2010)

[4] PIMPER László: Ultra könnyü ipari gyorsbeavatkozó gépjármü - Egy ötlet evolúciója és megvalósitása, Védelem - Katasztrófa- Tüz- És Polgári Védelmi Szemle 25.: 3. pp. 15-17. , 3 p. (2018) 
[5] KANYÓ Ferenc: UHPS- Ultra magasnyomású oltóberendezés, Védelem Katasztrófavédelmi Szemle 22 : 5 pp. 21-23. Paper: ISSN:2064-1559 , 3 p. (2015)

[6] KUTI Rajmund: A víz tüzoltói felhasználhatóságának lehetöségei, korlátai, Védelem Online: Tüz- és Katasztrófavédelmi Szakkönyvtár 2015: tanulmány 536 pp. 1-8. , 8 p. (2015), http://www.vedelem.hu/letoltes/anyagok/536-a-viz-tuzoltoifelhasznalhatosaganak-lehetosegei-korlatai.pdf

[7] SVÁB Attila: A marhabőrtől a ,, lélekig”, Budapest, Védelem 1996. 3. évf. 4. szám 9. oldal

[8] Darell GILBERT: History of Fire Hose, http://www.crownshoptalk.com/History\%20of\%20Fire\%20Hose.pdf, letöltés ideje: 2019. 05. 28.

[9] Robert AVSEC: LDH: Get big water to big fire, https://www.firerescue1.com/fireproducts/tools/hoses/articles/1313650-LDH-Get-big-water-to-big-fire/, letöltés ideje: 2019. 05. 28.

[10] RESTÁS Ágoston, PÁNTYA Péter, RÁCZ Sándor, ÉRCES Gergő, HESZ József, BODNÁR László: A komplexitás értelmezése a tüzvédelmi és mentésirányitási tanszék oktatási és kutatási tevékenységében, Tüzvédelmi Szakmai Nap tudományos konferencia, Szentendre, 2018. április 18. 